\title{
Aucklandia lappa Causes Membrane Permeation of Candida albicans
}

\author{
Heung-Shick Lee ${ }^{1}$ and Younhee $\mathrm{Kim}^{2 *}$ \\ ${ }^{1}$ Department of Biotechnology and Bioinformatics, Korea University, Sejongsi 30019, Republic of Korea \\ ${ }^{2}$ Department of Korean Medicine, Semyung University, Jecheon 27136, Republic of Korea
}

Candida albicans is a major fungal pathogen in humans. In our previous study, we reported that an ethanol extract from Aucklandia lappa weakens $C$. albicans cell wall by inhibiting synthesis or assembly of both (1,3)- $\beta$-D-glucan polymers and chitin. In the current study, we found that the extract is involved in permeabilization of $C$. albicans cell membranes. While uptake of ethidium bromide (EtBr) was $\mathbf{3 . 0 \%}$ in control cells, it increased to $7.4 \%$ for $\mathbf{3 0} \mathrm{min}$ in the presence of the A. lappa ethanol extract at its minimal inhibitory concentration (MIC), $0.78 \mathrm{mg} / \mathrm{ml}$, compared to uptake by heat-killed cells. Besides, leakage of DNA and proteins was observed in A. lappa-treated C. albicans cells. The increased uptake of EtBr and leakage of cellular materials suggest that $A$. Iappa ethanol extract induced functional changes in C. albicans cell membranes. Incorporation of diphenylhexatriene (DPH) into membranes in the A. Iappa-treated C. albicans cells at its MIC decreased to $84.8 \%$, after $60 \mathrm{~min}$ of incubation, compared with that of the controls, indicate that there was a change in membrane dynamics. Moreover, the anticandidal effect of the A. Iappa ethanol extract was enhanced at a growth temperature of $40^{\circ} \mathrm{C}$ compared to that at $35^{\circ} \mathrm{C}$. The above data suggest that the antifungal activity of the $A$. lappa ethanol extract against $C$. albicans is associated with synergistic action of membrane permeabilization due to changes in membrane dynamics and cell wall damage caused by reduced formation of $(1,3)-\beta$-D-glucan and chitin.

Keywords: Aucklandia lappa, Candida albicans, cell membrane, DPH, permeability

Received: September 25, 2020 Accepted: November 2, 2020

First published online: November 4, 2020

* Corresponding author Phone: +82-43-649-1346 Fax: +82-43-649-1341 E-mail:ykim@semyung.ac.kr

Supplementary data for this paper are available on-line only at http://jmb.or.kr.

pISSN 1017-7825 eISSN 1738-8872

Copyright(C) 2020 by The Korean Society for Microbiology and Biotechnology

\section{Introduction}

Candida species are commensal yeasts that constitute normal human microbial flora of the skin, oral cavity, vagina, and gastrointestinal tract, but they are also the most common cause of opportunistic fungal pathogens in humans under conditions of incompetent host immunity [1]. Candida albicans is a principal cause of candidiasis. However, there has been a shift toward non-albicans Candida species; C. tropicalis, C. glabrata, C. krusei. C. kefyr, C. parapsilosis, C. guilliermondii, and C. dubliniensis are now commonly identified in Candida infections [2]. Despite intensive studies to explore new antifungal drugs, currently available drugs for treatment of candidiasis are restricted. Eukaryotic pathogens, including Candida species, share a close evolutionary relationship with their human hosts, which limits drug targets that can be utilized to kill the pathogen selectively [3]. There are four major classes of antifungals [4]: First, echinocandins change cell wall biosynthesis by inhibiting $(1,3)-\beta$-D-glucan synthase. Second, polyenes target the membrane by binding to ergosterol and promoting the formation of transmembrane channels, resulting in cellular ionic imbalance and cell death [5]. Third, azoles alter the cell membrane by inhibiting lanosterol-14a-demethylase for ergosterol biosynthesis [6]. Finally, fluoropyrimidines block the synthesis of fungal nucleic acids [7]. However, the emergence of multi-drug resistant C. auris [8], harmful side effects of currently available antifungals, and the ability of Candida to form biofilms all pose a serious health problem [9]. Thus, it is essential to expedite new effective antifungals, with new targets and inhibitory activity. Plant products are good candidates for these novel antifungals, since they have been used traditionally in ethnomedicine worldwide; many of these have been shown to have antimicrobial or antifungal activities able to treat various diseases [10]. In our previous research, we found that an ethanol extract from A. lappa has antifungal activity against $C$. albicans; the extract is associated with cell wall damage through inhibiting synthesis or assembly of both $(1,3)-\beta$-D-glucan polymers and chitin [11]. Here, we demonstrate that the A. lappa ethanol extract is also involved in changing membrane permeability. 


\section{Materials and Methods \\ Candida Strain \\ C. albicans SC5314, purchased from the American Type Culture Collection (USA), was used for the study.}

\section{Preparation of the A. lappa Ethanol Extract}

The A. lappa ethanol extract was prepared as described previously [11]. Briefly, dried A. lappa roots were soaked in $70 \%$ ethanol, concentrated, and lyophilized to obtain an A. lappa ethanol extract. The extract was dissolved in dimethyl sulfoxide (DMSO) to $100 \mathrm{mg} / \mathrm{ml}$, filter-sterilized, and stored at $-20^{\circ} \mathrm{C}$ until use.

\section{Calcofluor White-Propidium Iodide Dual Staining}

C. albicans SC5314 cells $\left(5 \times 10^{6}\right.$ cells $\left./ \mathrm{ml}\right)$ were grown in YM media ( $10 \mathrm{~g}$ dextrose, $3 \mathrm{~g}$ malt extract, $5 \mathrm{~g}$ peptone and $3 \mathrm{~g}$ yeast extract in 1 liter of distilled water) in the presence of DMSO or $0.78 \mathrm{mg} / \mathrm{ml}$ of the A. lappa ethanol extract, incubated at $200 \mathrm{rpm}$ and $37^{\circ} \mathrm{C}$ for $2.5 \mathrm{~h}$. The cells were harvested, washed with phosphate-buffered saline (PBS, pH 7.4) (Invitrogen, USA), and stained with $10 \mu \mathrm{g} / \mathrm{ml}$ propidium iodide (PI) and $0.01 \%$ Calcofluor White M2R (Sigma, USA) in PBS (pH 7.4) for 5 min. Cells were examined using a bright-field microscope or a fluorescence microscope equipped with triple bandpass filters.

\section{Ethidium Bromide (EtBr)-Uptake Assay}

The alteration of membrane permeability was investigated by EtBr uptake according to Rodrigues [12] with slight modifications. The uptake assay of EtBr was carried out using a fluorometer (Tecan, Austria). Exponentialphase C. albicans SC5314 cells were collected, washed with PBS ( $\mathrm{pH} 7.4$ ), and resuspended in PBS (pH 7.4) containing $1 \mu \mathrm{g} / \mathrm{ml} \mathrm{EtBr}$ and $5 \mathrm{mM}$ glucose to obtain a final cell density of $1 \times 10^{8}$ cells $/ \mathrm{ml}$. Aliquots of $450 \mu \mathrm{l}$ cell suspension were distributed into 5 microtubes, and DMSO or A. lappa ethanol extract was added at concentrations ranging from 0.39 to $1.56 \mathrm{mg} / \mathrm{ml}$. Heat-killed cells were prepared by incubating the sample at $80^{\circ} \mathrm{C}$ for $10 \mathrm{~min}$. One-hundred- $\mu \mathrm{l}$ aliquots of each sample were placed into a 96-well black/clear flat-bottom microplate (BD Falcon) in quadruplicate, and the foil-covered plate was incubated at $25^{\circ} \mathrm{C}$. EtBr uptake in the C. albicans SC5314 cells was measured using a fluorometer, and fluorescence data were acquired at an excitation wavelength of 530 $\mathrm{nm}$ (bandwidth of $25 \mathrm{~nm}$ ) and emission wavelength of $585 \mathrm{~nm}$ (bandwidth of $20 \mathrm{~nm}$ ). Fluorescence intensity (arbitrary unit) of EtBr uptake in heat-killed cells was taken as 100, and uptake in cells treated with the A. lappa extract was represented as a percentage.

\section{Leakage of Cellular Materials}

To determine whether the antifungal effect of the A. lappa ethanol extract is related to the permeability change in the C. albicans cell membrane, cellular leakage was assessed by fluorometric or spectrophotometric method. C. albicans cells in YM $\left(1 \times 10^{9}\right.$ cells $\left./ \mathrm{ml}\right)$ were incubated in the presence of the A. lappa ethanol extract $(0.78 \mathrm{mg} / \mathrm{ml})$ or the same volume of $\mathrm{DMSO}$ at $37^{\circ} \mathrm{C}$ at $200 \mathrm{rpm}$ for $60 \mathrm{~min}$. Then, C. albicans cells were washed twice with PBS ( $\mathrm{pH}$ 7.4) by centrifugation at $12,000 \times g$ for $2 \mathrm{~min}$, resuspended in PBS ( $\mathrm{pH} 7.4$ ), and further incubated at $37^{\circ} \mathrm{C}$ with agitation. At $20 \mathrm{~min}$ intervals, $0.6 \mathrm{ml}$ cell suspension was removed and centrifuged at $12,000 \times g$ for $10 \mathrm{~min}$, and the supernatant was saved for further analysis. The leakage of nucleotides was quantified using Qubit dsDNA BR (broad range) Assay Kit according to manufacturer instructions by Qubit 4.0 Fluorometer (Thermo Fisher, USA). To evaluate protein leakage, the absorbance of the supernatant $(100 \mu \mathrm{l})$ mixed with Bradford reagent (Bio-Rad) was read at $595 \mathrm{~nm}$ using a microplate reader.

\section{Diphenylhexatriene (DPH) Incorporation into C. albicans Membranes}

Log-phase C. albicans cells $\left(5 \times 10^{8}\right.$ cells $\left./ \mathrm{ml}\right)$ were incubated in the presence of DMSO or A. lappa ethanol extract at $37^{\circ} \mathrm{C}$ with agitation at $200 \mathrm{rpm}$. Every $30 \mathrm{~min}$, a sample from each group of cell culture $(0.9 \mathrm{ml})$ was centrifuged, washed with PBS ( $\mathrm{pH}$ 7.4), and resuspended in PBS containing $50 \mu \mathrm{M} \mathrm{DPH}$. Aliquots $(0.2 \mathrm{ml})$ of each sample were distributed into a 96-well black/clear flat-bottom microplate in quadruplicate and further incubated at $25^{\circ} \mathrm{C}$ for $20 \mathrm{~min}$ in the dark on a rocker. Fluorescence was measured using a spectrofluorometer at $340 \mathrm{~nm}$ with a $20 \mathrm{~nm}$ bandwidth and $430 \mathrm{~nm}$ with a $20 \mathrm{~nm}$ bandwidth as excitation and emission wavelengths, respectively. The effect of A. lappa treatments compared with controls was analyzed using SigmaPlot 13.0. A p value less than 0.05 was regarded as statistically significant.

\section{Effect of Higher Temperature on Anticandidal Activity of A. lappa Extract}

C. albicans cells were collected and the pellet was suspended in YM medium at $\mathrm{A}_{595}=0.15$. The cell suspension was mixed with DMSO or $0.39 \mathrm{mg} / \mathrm{ml}$ of $A$. lappa ethanol extract, and $200 \mu$ laliquots of each sample were placed in quadruplicate in two 96-well flat-bottom microtiter plates. Then, each microplate was incubated with moist air at $35^{\circ} \mathrm{C}$ and $40^{\circ} \mathrm{C}$, respectively, and cell growth was examined by measuring the absorbance of each culture at $595 \mathrm{~nm}$ every hour using a spectrofluorometer. Prior to measuring absorbance, microplates were agitated for $20 \mathrm{~s}$.

\section{Changes in Electrolyte Concentration}

Twenty $\mathrm{ml}$ of overnight $C$. albicans cells were harvested by centrifugation at $12,000 \times \mathrm{g}$ for $10 \mathrm{~min}$ at $4^{\circ} \mathrm{C}$ and washed with cold PBS ( $\mathrm{pH}$ 7.4). The cell pellet was suspended in $3 \mathrm{ml}$ cold PBS, and the cell suspension was placed into 6 tubes. The A. lappa ethanol extract or DMSO corresponding to $0.5 \times$ minimal inhibitory concentration (MIC), $1 \times$ MIC, or $2 \times$ MIC was added, and tubes were incubated on ice with slight agitation on an orbital shaker. After 60 min, each cell suspension was harvested and washed twice with PBS (pH 7.4). Then, the pellet was 
resuspended in $0.5 \mathrm{ml}$ PBS and incubated for an additional $30 \mathrm{~min}$ on ice with slight agitation. Subsequently, each cell suspension was centrifuged at $12,000 \times g$ at $4^{\circ} \mathrm{C}$ for $10 \mathrm{~min}$, and the supernatant was saved for further analysis. The sodium, potassium, and chloride concentrations of each supernatant were measured using an electrolyte analyzer (SmartLyte, USA) after the instrument was calibrated using analytical grade sodium, potassium, and chloride QC standards. The sodium and potassium data are shown.

\section{Results and Discussion}

Our earlier studies on A. lappa ethanol extract demonstrated that the extract has antifungal activity against Candida species, and the MIC of the A. lappa ethanol extract against C. albicans SC5314 was found to be $0.78 \mathrm{mg} / \mathrm{ml}$ [11] as follows. Chitin content was reduced to $79.8 \%$ relative to control after incubation with A. lappa ethanol extract at its MIC for $6 \mathrm{~h}$. Synthesis of $(1,3)$ - $\beta$-D-glucan polymers was inhibited to $84.3 \%$ of control treatment following incubation of $C$. albicans microsomes with the A. lappa extract at its MIC. This indicates that A. lappatreated cells with weakened cell walls are more sensitive to osmotic pressure. In fact, A. lappa-treated C. albicans cells survived in the presence of $0.8 \mathrm{M}$ sorbitol, as demonstrated by the fact that $A$. lappa extract MIC against C. albicans cells demonstrated an eight-fold increase from $0.78 \mathrm{mg} / \mathrm{ml}$ to $6.24 \mathrm{mg} / \mathrm{ml}$ in 3 days [11]. The present study was designed to show that $A$. lappa ethanol extract is also involved in membrane damage in C. albicans cells.

\section{Dual Staining with Calcofluor White and PI}

Calcofluor White, a fluorescent dye that appears blue under ultraviolet light, stains the chitin layer in the cell walls of fungi [13]. PI, a red fluorescent dye, is a cationic molecule that is able to pass through a damaged cell membrane, but is unable to enter into cells with an intact cell membrane. Consequently, dead or dying cells with defective cell membranes are characterized by red fluorescence signals, while those with intact cell membranes are not stained with PI [14]. C. albicans SC5314 cells treated with DMSO or ethanol extract of A. lappa at $37^{\circ} \mathrm{C}$ for $2.5 \mathrm{~h}$ were stained with Calcofluor White and PI, then observed under bright-field and fluorescence microscopy. In contrast to blue cells with intact cell membranes in the controls (Fig. 1C), some pink cells were found among A. lappa-treated cells, indicating that these cells were sick or dead with damaged cell membranes (Fig. 1D). Moreover, clumps with beige fluorescence seemed to be dead cell aggregates with severely injured membranes without rupture (Fig. 1D). Aggregate formation may occur through cooperation with individual cells, since cell aggregation is known to be stimulated by cell adhesion molecules, secreted enzymes, and molecules that promote
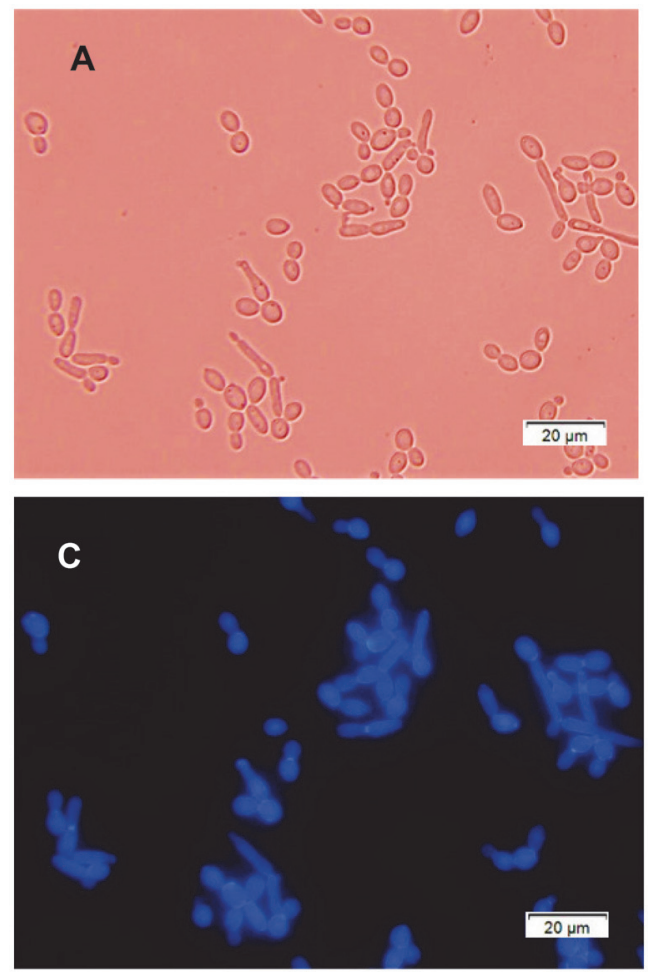

No treatment
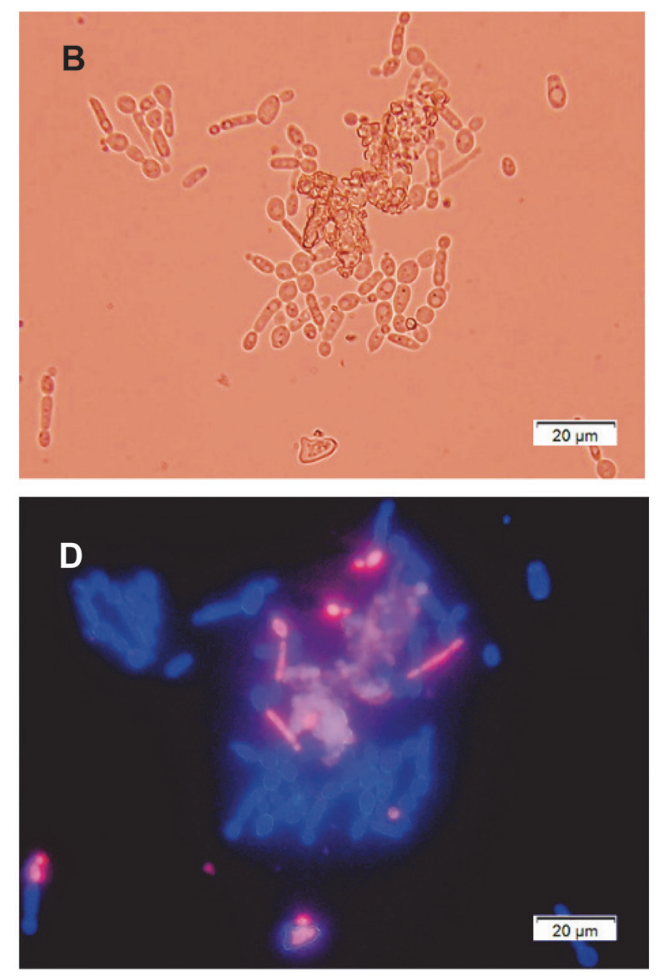

A. lappa

Fig. 1. Membrane-damaged C. albicans cells shown by Calcofluor White-PI dual staining. C. albicans cells treated with DMSO (A and $\mathbf{C}$ ) or the A. lappa ethanol extract (B and D) for $2.5 \mathrm{~h}$ were stained with both $10 \mu \mathrm{g} / \mathrm{ml}$ PI and $0.01 \%$ Calcofluor White, and observed with a bright-field microscope (A and $\mathbf{B}$ ) or a fluorescence microscope equipped with triple bandpass filters. The Candida cell walls were stained blue with Calcofluor White (C and D), and cells with damaged membranes were stained pink with PI (D). Beige aggregates are the cell clusters with severely injured cell membranes in the center (D). 
quorum sensing in yeast [15], which is a virulence factor for fungal adhesion and colonization [16]. Aggregate formation in A. lappa-treated cells is assumed to be a protective response against harsh conditions imposed by the A. lappa ethanol extract. Based on data from PI staining, we examined whether A. lappa ethanol extract affects the function of $C$. albicans membranes by EtBr-uptake assay.

\section{EtBr-Uptake Assay}

The fluorescent probe EtBr is an intercalating agent resembling a DNA base pair. The molecule emits weak fluorescence in aqueous solution, but exhibits a 20 - to 25 -fold fluorescence enhancement upon binding to doublestranded DNA [17]. Due to its charged and polar nature, EtBr cannot penetrate intact membranes. While the molecule is able to enter damaged cells rapidly, where it binds mainly to DNA, the dye is mostly excluded by intact cells [18]. Therefore, EtBr is commonly used to indicate cell membrane integrity. In our preliminary experiment, C. albicans cells incubated with $40 \mu \mathrm{g} / \mathrm{ml} \mathrm{EtBr}$ for $30 \mathrm{~min}$ were visualized by fluorescence microscopy, and a considerable degree of orange fluorescence and weak orange fluorescence were detected in the nucleus and the cytoplasm, respectively, irrespective of treatment with A. lappa ethanol extract (Fig. S1). In contrast to the previous report, a high concentration of $\mathrm{EtBr}$ is thought to penetrate cell membranes by passive transport or other mechanisms. In addition, it is thought that EtBr binds double-stranded DNA strongly in the nucleus and basepaired RNA or DNA-RNA hybrid weakly in the cytoplasm. Nonetheless, the A. lappa-treated cells appeared to fluoresce orange more intensely in both the nucleus and cytoplasm relative to controls. These results suggest that A. lappa ethanol extract is involved in damaging C. albicans cell membranes. To explore these findings further, the experiment was modified to quantify membrane damage using a fluorometer. In the EtBr-uptake assay, C. albicans cells in PBS containing $5 \mathrm{mM}$ glucose and $1 \mu \mathrm{g} / \mathrm{ml} \mathrm{EtBr}$ were incubated with DMSO or the A. lappa ethanol extract at $25^{\circ} \mathrm{C}$. Glucose was added to the buffer to promote efflux system activity. Fluorescence intensity of EtBr (in AU, arbitrary units) in A. lappa-treated C. albicans cells was represented as a percentage, while that of heat-killed cells was set as 100. Uptake of EtBr by DMSO-treated controls was $2.5 \pm 0.1 \%$ compared to heat-killed cells at $10 \mathrm{~min}$ (Fig. 2). Uptake of EtBr by A. lappa-treated cells at $0.39 \mathrm{mg} / \mathrm{ml}, 0.78 \mathrm{mg} / \mathrm{ml}$, and $1.56 \mathrm{mg} / \mathrm{ml}$ was $4.1 \pm 0.2 \%, 5.6 \pm 0.3 \%$, and $9.3 \pm 0.6 \%$ at $10 \mathrm{~min}$, respectively, relative to heat-killed cells. There was a statistically significant difference between $A$. lappa-treated or heat-treated and DMSO control group $(p<0.001)$. Furthermore, A. lappa-treated cells showed significant uptake of EtBr in C. albicans cells after 20, 30, and $40 \mathrm{~min}$ compared to controls $(p<0.001)$. As shown in Fig. 2, EtBr uptake by A. lappa-treated cells increased slowly in a time- and concentration-dependent manner. Thus, it appears that more EtBr molecules easily enters across the damaged cell membranes of the A. lappa-treated C. albicans cells and intercalate into DNA or DNA-RNA hybrid gradually. The data demonstrate that A. lappa ethanol extract brings about permeabilization in C. albicans membranes and support those of PI staining (Fig. 1D).

\section{Leakage of Cellular Materials}

UV absorbance spectrophotometry is a commonly used method for quantification of nucleic acids, since DNA and RNA have high absorbance peaks at $260 \mathrm{~nm}$. Initially, we used the spectrometric method, but it was so delicate that the nucleotide data were not stable. Therefore, the leakage of nucleotides was estimated using Qubit dsDNA BR Assay Kit, which is based on fluorescence, and used for the quantification of double-strand DNA samples. As shown in Fig. 3, both DNA and proteins were detected in the extracellular buffer of the A. lappa extract-treated

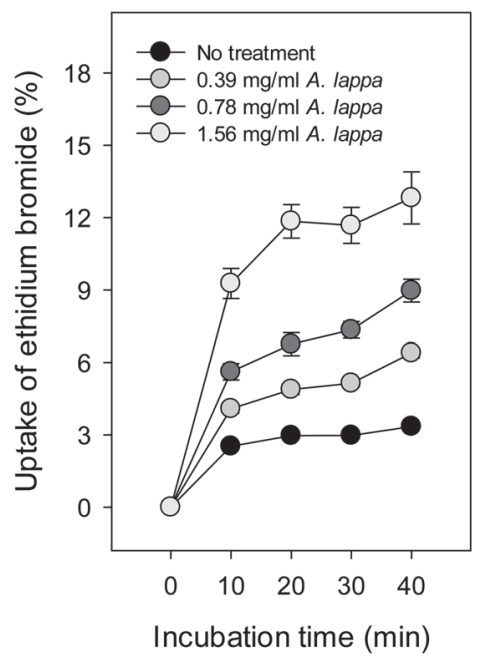

Fig. 2. Uptake of ethidium bromide. C. albicans cells in PBS (pH 7.4) containing $1 \mu \mathrm{g} / \mathrm{ml} \mathrm{EtBr}$ and $5 \mathrm{mM}$ glucose were incubated with DMSO or the A. lappa ethanol extract. Heat-killed cells were included as a positive control. Amount of EtBr uptake by C. albicans cells was estimated using a fluorometer, and fluorescence intensity of the heat-killed cells was taken as 100 . Three independent experiments were performed and the data represent the mean and standard deviations from a representative experiment 

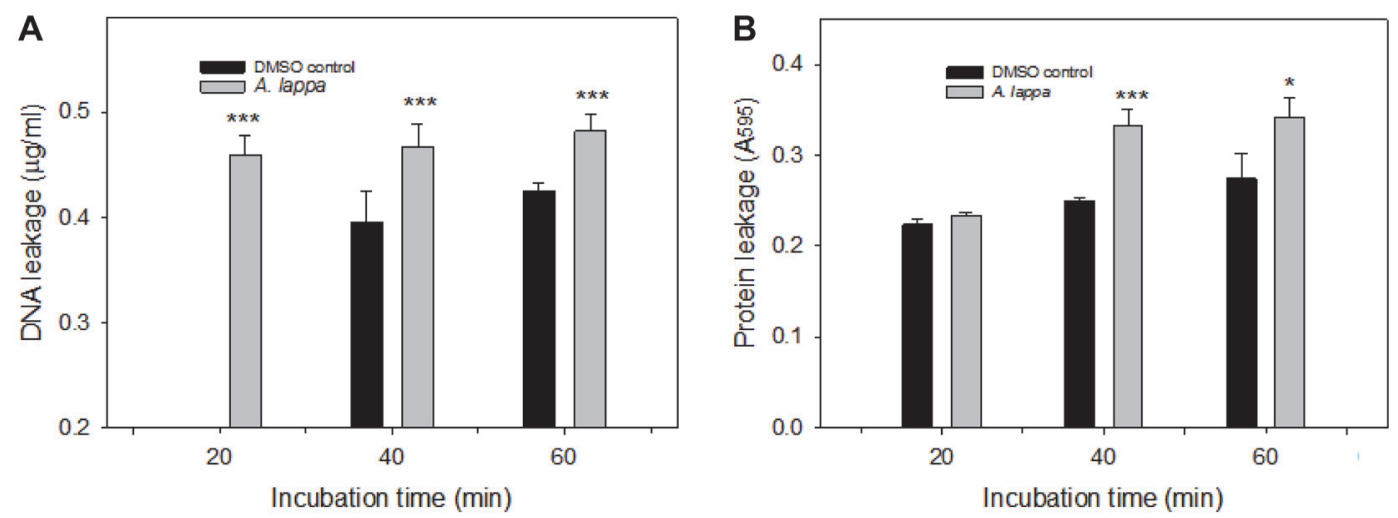

Fig. 3. Leakage of cellular materials. C. albicans cells treated with DMSO or A. lappa ethanol extract were washed with PBS ( $\mathrm{pH}$ 7.4) twice, and incubated further as indicated. Then, each cell suspension was centrifuged and the supernatant was analyzed for (A) the leakage of DNA and (B) protein leakage, the absorbance at $595 \mathrm{~nm}$ of the supernatant with Bradford reagent. The data represent average values and standard deviations obtained in three independent experiments. ${ }^{\star} p<0.05$, ${ }^{* * *} p<0.001$

cells. It is surprising that $0.396 \pm 0.018 \mu \mathrm{g} / \mathrm{ml}$ DNA was detected in the extracellular buffer of the DMSO control cells at $40 \mathrm{~min}$, although no detectable amount of DNA was found at $20 \mathrm{~min}$. Nevertheless, the amount of leaked DNA was higher in the extracellular buffer of the A. lappa-treated cells at 20, 40, and $60 \mathrm{~min}$, respectively, compared with that of the DMSO controls (Fig. 3A). There was a statistically significant difference between the control and each $A$. lappa-treated group $(p<0.001)$.

The Bradford assay was carried out for protein quantification [19] according to the manufacturer's instructions (Bio-Rad). Proteins were detected in the extracellular buffer of both the A. lappa-treated cells and the DMSO controls, too. Since the Bradford assay is a colorimetric assay, it was expected that the extracellular buffer of the A. lappa-treated cells contains much more proteins judged by the deeper-blue color of the samples. However, the difference of the extracellular buffer between the A. lappa-treated cells and DMSO controls was not statistically significant at $20 \mathrm{~min}$. There was a statistically significant difference between the control and A. lappa-treated groups after $40 \mathrm{~min}(p<0.05)$. The reason why leakage of DNA and proteins were found in the extracellular buffer of the DMSO controls is assumed to be due to the presence of $0.78 \%$ DMSO, which is a solvent for the ethanol extract of A. lappa, and high concentration of C. albicans $\left(1 \times 10^{9}\right.$ cells $\left./ \mathrm{ml}\right)$ in the assay. In our preliminary experiment, more than $1 \%$ DMSO showed toxic effects on red blood cells. Regardless of the effect of DMSO, it is certain that the A. lappa ethanol extract made cellular leakage effects on C. albicans cells.

\section{DPH Intercalation into C. albicans Cell Membranes}

$\mathrm{DPH}$ is a membrane probe commonly used to study fluorescence anisotropy; rotational motion of DPH is monitored to investigate membrane fluidity and lipid ordering [20]. Whether changes in membrane permeability are related to the lipid composition or arrangement of $C$. albicans cell membranes was assessed, and DPH intercalation into the membranes of DMSO controls and A. lappa-treated cells was compared. DPH is not

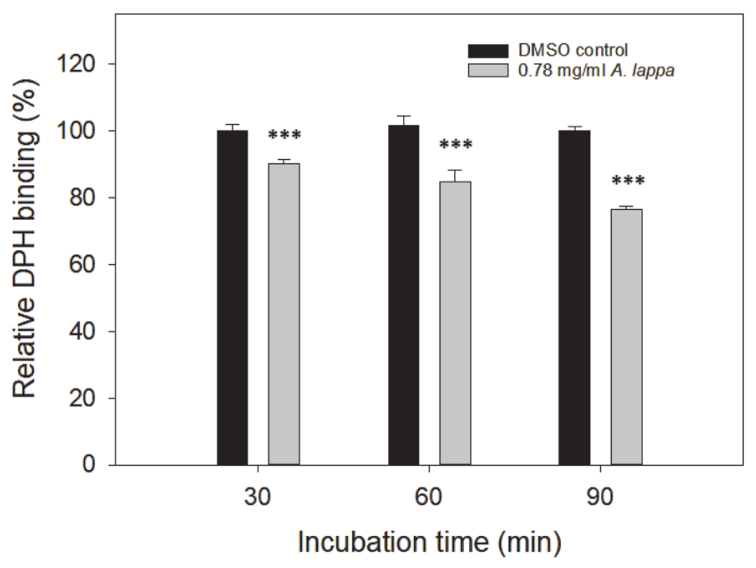

Fig. 4. DPH intercalation into C. albicans cell membranes. C. albicans cells treated with DMSO or the A. lappa ethanol extract at $37^{\circ} \mathrm{C}$ were resuspended in PBS (pH 7.4) containing $50 \mu \mathrm{M} \mathrm{DPH}$. Then, fluorescence of each sample was measured using a spectrofluorometer. The data represent average values and standard deviations obtained in three independent experiments. ${ }^{* *} p<0.001$. 
A

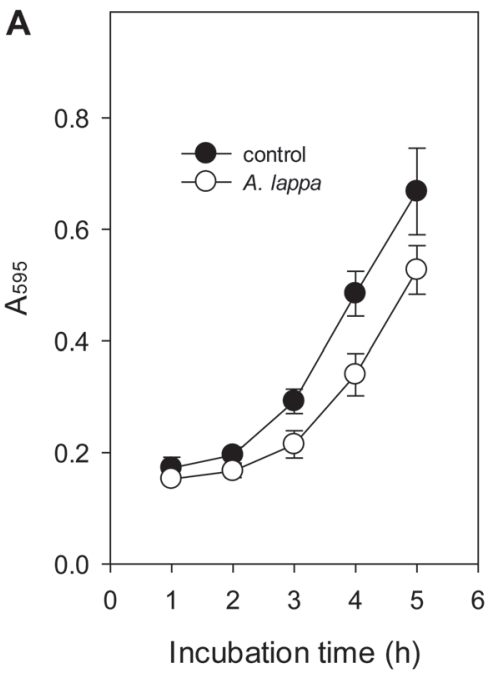

B

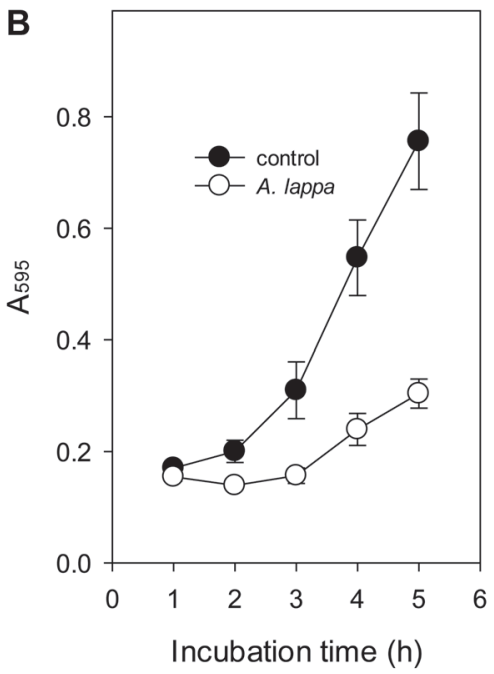

Fig. 5. Effect of higher temperature on anticandidal activity of the A. lappa extract. Exponential-phase C. albicans cells $\left(\mathrm{A}_{595}=0.15\right)$ were incubated with DMSO or the A. lappa ethanol extract at $35^{\circ} \mathrm{C}(\mathbf{A})$ and $40^{\circ} \mathrm{C}(\mathbf{B})$, respectively. Every hour, cell growth was checked by measuring the absorbance of each sample at $595 \mathrm{~nm}$. Data represent average values and standard deviations obtained in two independent experiments.

fluorescent in water but strongly fluorescent after intercalation into lipid membranes. When added to the DMSOtreated or the A. lappa-treated C. albicans cells, DPH intercalated within the acyl chain region of the lipid bilayer, but any differences in fluorescence intensity between treatment groups are related to changes in the arrangement or composition of acyl chains. Relative intercalation of DPH into the A. lappa-treated cells at its MIC was $90.3 \pm$ $1.2 \%, 84.8 \pm 3.5 \%$, and $76.5 \pm 0.8 \%$ after 30,60 , and 90 min of incubation, respectively, compared with that of the DMSO controls (Fig. 4). There was a statistically significant difference between the control and A. lappa-treated groups $(p<0.001)$. Decreased intercalation of DPH into A. lappa-treated C. albicans membranes suggests that there was a change in membrane dynamics due to the alteration of lipid arrangement or composition. Increased membrane fluidity is related to a high density of fatty acids with short chains, unsaturated fatty acids, or low density of ergosterol. When the extract was examined for effects on ergosterol synthesis, no significant effect was detected (data not shown).

Effect of Higher Temperature on Anticandidal Activity of A. lappa Extract

The growth of C. albicans cells at $35^{\circ} \mathrm{C}$ and $40^{\circ} \mathrm{C}$ in the presence of DMSO or A. lappa ethanol extract at $0.39 \mathrm{mg} / \mathrm{ml}$ was compared by measuring the absorbance at $595 \mathrm{~nm}$ hourly (Fig. 5). DMSO control cells grew faster at $40^{\circ} \mathrm{C}$ than at $35^{\circ} \mathrm{C}$, while $A$. lappa-treated cells grew more slowly at $40^{\circ} \mathrm{C}$ than at $35^{\circ} \mathrm{C}$. That is, the A. lappa ethanol extract showed better antifungal activity at higher temperatures. We can assume that the anticandidal effect of $A$. lappa ethanol extract against $C$. albicans is enhanced because of the synergistic effect of increased membrane fluidity at higher temperatures with the membrane perturbation caused by the extract.

\section{Changes in Electrolyte Concentration}

C. albicans cells treated with DMSO or A. lappa ethanol extract for $60 \mathrm{~min}$ were washed, and cells were incubated for an additional $30 \mathrm{~min}$. Cells were then harvested, and the supernatant was saved to evaluate sodium, potassium, and chloride concentrations using an electrolyte analyzer. When C. albicans cells were treated with $0.5 \times \mathrm{MIC}(0.39 \mathrm{mg} / \mathrm{ml})$ of $A$. lappa ethanol extract, the sodium concentration of the supernatant was $159 \mathrm{mM}$, the same as that of the DMSO control (Fig. 6A). However, when C. albicans cells were incubated with $1 \times$ MIC or $2 \times$ MIC of A. lappa ethanol extract, the sodium concentration of the extracellular supernatant increased from $159 \mathrm{mM}$ to $160 \mathrm{mM}$ and $161 \mathrm{mM}$, respectively, whereas that of the DMSO control cells remained the same at $159 \mathrm{mM}$ (Fig. 6A). In contrast, when C. albicans cells were exposed to $2 \times$ MIC of A. lappa ethanol extract, the potassium concentration of the supernatant decreased from $3.3 \mathrm{mM}$ to $2.5 \mathrm{mM}$, although that of the DMSO control remained stable at approximately $3.4 \mathrm{mM}$ (Fig. 6B). That is, $2 \mathrm{mM}$ sodium ion flowed out and $0.8 \mathrm{mM}$ potassium ion flowed in following treatment with $A$. lappa extract at $1.56 \mathrm{mg} / \mathrm{ml}$ for $60 \mathrm{~min}$. However, the extracellular chloride concentration of the DMSO control and A. lappa-treated C. albicans cells remained the same at $151 \mathrm{mM}$ (data not shown). Potassium is essential for many cellular functions, including regulation of cell volume and intracellular $\mathrm{pH}$, maintenance of stable membrane potential, compensation of negative charges in many macromolecules, protein synthesis, and enzyme activation [21]. Potassium can be highly accumulated in different types of living cells due to its essential role in many physiological functions. In contrast to the essential function of potassium ions, high concentrations of sodium are toxic to cells. Therefore, yeast cells maintain an optimum intracellular concentration of potassium ions and a high intracellular $\mathrm{K}^{+} / \mathrm{Na}^{+}$ratio with three different strategies: transporters display higher affinity for potassium than for sodium, toxic or surplus cations undergo 

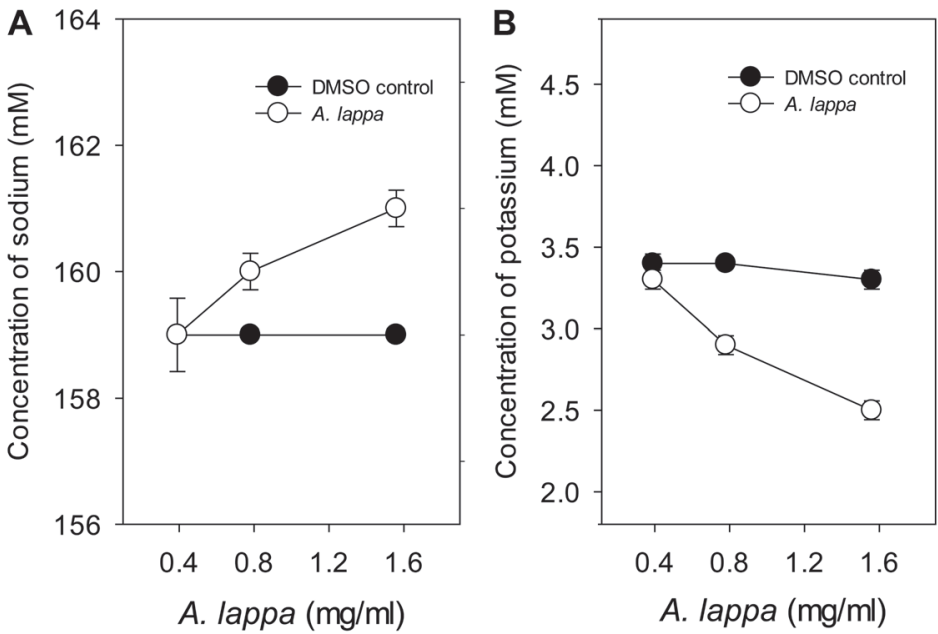

Fig. 6. Changes in electrolyte concentration of C. albicans. Overnight cultures of C. albicans cells (50 ml) were suspended in cold PBS ( $\mathrm{pH}$ 7.4) and incubated in the presence of DMSO or A. lappa ethanol extract for 60 min. Each cell culture was harvested, resuspended in PBS (pH 7.4), and incubated for an additional $30 \mathrm{~min}$. Then, each sample was centrifuged, and the supernatant was subjected to electrolyte analysis. Sodium and potassium concentrations of each supernatant were measured using an electrolyte analyzer; these data represent one of the results from three repeated experiments.

efficient efflux from cells, and organelles selectively sequester cations [21].

On the basis of the increased uptake of EtBr data, we conclude that $A$. lappa ethanol extract generated functional changes in C. albicans cell membranes. In particular, A. lappa-treated C. albicans cells seemed to be damaged in membrane structure. In terms of membrane permeabilization, DNA and proteins were found in the extracellular buffer of A. lappa-treated C. albicans cells. Reduction of DPH intercalation into A. lappa-treated cells indicates alterations in lipid composition or arrangement, followed by increased membrane permeability in C. albicans cells. The enhanced antifungal activity of $A$. lappa extract at the elevated temperature of $40^{\circ} \mathrm{C}$ supports the hypothesis that membrane permeability by the extract is amplified at higher temperatures. Perturbation of cell membranes, leakage of proteins or salts, or influx of salts are involved in destabilizing the osmotic balance of C. albicans cells. Changes in sodium and potassium ion concentrations occurred in the extracellular buffer of A. lappa-treated cells, possibly restoring osmotic balance in response to membrane permeabilization. Nevertheless, cell aggregates were frequently formed by A. lappa treatment. The aggregates might be formed by membrane-membrane fusion among individual cells with weakened cell walls. Aggregate formation could be a protective response for adhesion for colonization, or it may be for switch from the yeast form to the hyphal form.

In conclusion, the antifungal effect of $A$. lappa ethanol extract is related to the synergistic action of the inhibition of cell wall synthesis and increased membrane permeability in C. albicans.

\section{Acknowledgments}

This study was supported by the Semyung University Research Grant of 2016

\section{Conflict of Interest}

The authors have no financial conflicts of interest to declare.

\section{References}

1. Kullberg BJ, Arendrup MC. 2015. Invasive candidiasis. N. Engl. J. Med. 373: 1445-1456

2. Deorukhkar SC, Saini S, Mathew S. 2014. Non-albicans Candida infection: an emerging threat. Interdiscip. Perspect. Infect. Dis. 2014: 615958.

3. Shapiro RS, Robbins N, Cowen LE. 2011. Regulatory circuitry governing fungal development, drug resistance, and disease. Microbiol. Mol. Biol. Rev. 75: 213-267.

4. Bondaryk M, Kurzątkowski W, Staniszewska M. 2013. Antifungal agents commonly used in the superficial and mucosal candidiasis treatment: mode of action and resistance development. Postepy Dermatol. Alergol. 30: 293-301.

5. Odds FC, Brown AJ, Gow NA. 2003. Antifungal agents: mechanisms of action. Trends Microbiol. 11: 272-279.

6. Bossche HV, Koymans L, Moereels H. 1995. P450 inhibitors of use in medical treatment: focus on mechanisms of action. Pharmacol. Ther. 67: 79-100.

7. Polak A, Scholer HJ. 1975. Mode of action of 5-fluorocytosine and mechanisms of resistance. Chemother 21: 113-130.

8. Kordalewska M, Perlin DS. 2019. Identification of drug resistant Candida auris. Front. Microbiol. 10: 1918.

9. Guevara-Lora I, Bras G, Karkowska-Kuleta J, González-González M, Ceballos K, Sidlo W, et al. 2020. Plant-derived substances in the fight against infections caused by Candida species. Int. J. Mol. Sci. 21: 6131.

10. Perumal Samy R, Gopalakrishnakone P. 2010. Therapeutic potential of plants as anti-microbials for drug discovery. Evid. Based Complement. Alternat. Med. 7:283-294.

11. Lee HS, Kim Y. 2020. Aucklandia lappa causes cell wall damage in Candida albicans by reducing chitin and $(1,3)$ - $\beta$-D-glucan. J. Microbiol. Biotechnol. 30: 967-973. 
12. Rodrigues L, Ramos J, Couto I, Amaral L, Viveiros M. 2011. Ethidium bromide transport across Mycobacterium smegmatis cell-wall: correlation with antibiotic resistance. BMC Microbiol. 11: 35

13. Brasch J, Kreiselmaier I, Christophers E. 2003. Inhibition of dermatophytes by optical brighteners. Mycoses 46: 120-125.

14. Lee HS, Kim Y. 2017. Paeonia lactiflora inhibits cell wall synthesis and triggers membrane depolarization in Candida albicans. J. Microbiol. Biotechnol. 27: 395-404.

15. Chow J, Dionne HM, Prabhakar A, Mehrotra A, Somboonthum J, Gonzalez B, et al. 2019. Aggregate filamentous growth responses in yeast. $m$ Sphere 4: e00702-18.

16. Kumar R, Saraswat D, Tati S, Edgerton M. 2015. Novel aggregation properties of Candida albicans secreted aspartyl proteinase Sap6 mediate virulence in oral candidiasis. Infect. Immun. 83: 2614-2026.

17. LePecq JB, Paoletti C. 1967. A fluorescent complex between ethidium bromide and nucleic acids: physical-chemical characterization. J. Mol. Biol. 27: 87-106.

18. Dive C, Watson JV, Workman P. 1990. Multiparametric analysis of cell membrane permeability by two colour flow cytometry with complementary fluorescent probes. Cytometry 11: 244-252.

19. Bradford MM. 1976. A rapid and sensitive method for the quantitation of microgram quantities of protein utilizing the principle of protein-dye binding. Anal. Biochem. 72: 248-254.

20. Repakova J, Čapková P, Holopainen JM, Vattulainen I. 2004. Distribution, orientation, and dynamics of DPH probes in DPPC bilayer. J. Phys. Chem. B. 108: 13438-13448.

21. Ariño J, Ramos J, Sychrová H. 2010. Alkali metal cation transport and homeostasis in yeasts. Microbiol. Mol. Biol. Rev. 74: 95-120. 